\title{
The Relationship Between Seed Coat Colour, Seed Quality and Yield Related Traits in Yardlong Bean (Vigna Unguiculata (L.) Walp.ssp. Unguiculata cv.-gr. Sesquipedalis)
}

Shubha Kumari ( $\nabla$ shubha.veg@gmail.com )

ICAR Parisar: ICAR Research Complex for Eastern Region

Arbind K Choudhary

ICAR-RCER: ICAR Research Complex for Eastern Region

Ayesa Eram

Aligarh Muslim University

Anirban Mukherjee

ICAR-RCER: ICAR Research Complex for Eastern Region

Ujjwal Kumar

ICAR-RCER: ICAR Research Complex for Eastern Region

Abhisek Dubey

ICAR-RCER: ICAR Research Complex for Eastern Region

\section{Short Report}

Keywords: Yardlong bean, seed coat colour, seed germination, yellow mosaic disease, yield

Posted Date: February 1st, 2022

DOl: https://doi.org/10.21203/rs.3.rs-1191552/v1

License: (c) (i) This work is licensed under a Creative Commons Attribution 4.0 International License.

Read Full License 


\section{Abstract}

Yardlong bean genotypes have wide variability in seed coat colours. This research sought to investigate association of seed coat colour with germination, yield and disease resistance of yardlong bean genotypes. Total nine yardlong beans genotypes three from each with different seed coat colours i.e. brown, black and bicolor were selected for this study. Eight important seed and horticultural traits like seed length, seed width, seed thickness, days of $50 \%$ flower, days of mature pods, average pod length, average pod width and pod yield per plant were recorded in all set of genotypes. Bicolor seed coat genotype exhibited highest germination percentage (85-100\%) followed by brown (71-84\%) and black (4359). Water uptake capacity was found highest in bicolor genotype i.e. RCPY-2 (240\%) followed by YB-7 (131.87\%) and RCPY-1 (141.17\%). Average pod length and pod yield per plant was also found highest in bicolor seed coat coloured genotype RCPY-2 (37.64 $\pm 11.03 \mathrm{~g})$ and $(1036.66 \pm 115.9 \mathrm{~g} / \mathrm{plant})$ respectively. We also studied the disease resistance to yellow mosaic disease caused by mungbean yellow mosaic India virus (MYMIV) in field condition. Results from preliminary screening for MYMIV showed that bicolor seeds were resistant to MYMIV. The RCPY-2, a bicolored genotype was recorded lowest disease incidence, which can use as donor to MYMIV resistance breeding of Yardlong bean.

\section{Introduction}

Yardlong bean alternatively known as Chinese long bean, string bean, snake bean, snake pea, snap pea, bodi, pea-bean and asparagus bean (Vigna unguiculata (L.) Walp.ssp. unguiculata cv.-gr. sesquipedalis) is a dicotyledonous crop in the order Fabaceae, subfamily Faboideae (Syn. Papillionoideae), tribe Phaseoleae, subtribe Phaseolinae, genus Vigna and section Catiang (Timko and Singh, 2008). Vigna which contains several important cultivated legume species including cowpea (V. unguiculata (L.) Walp.ssp. unguiculata), blackgram ( $V$. mungo (L.) Hepper), mungbean ( $V$. radiata (L.)Wilczek), bambara groundnut ( $V$. subterranea), moth bean ( $V$. aconitifolia), adzuki bean $(V$. angularis) and rice bean $(V$. umbellata). Yardlong bean and cowpea are in the subgenus Vigna, whereas the mungbean and blackgram are in the subgenus Ceratotropis (Pasquet, 2001). Unlike other Vigna crops, yardlong bean is grown primarily for its crisp and tender pods, which can be eaten raw or cooked. Yardlong bean characterized by its very long $(30-90 \mathrm{~cm}$ in length) succulent pods with seeds usually 8-12 $\mathrm{mm}$ long whereas cowpea has shorter pod (20-30 cm in length) (Verdcourt 1970). It is rich source of protein (25\%), carbohydrates (64\%), vitamins, fiber and folic acid (Hall, 2012; Timko and Singh, 2008). The world production of yardlong bean exceeds 17 million tons and productivity is $13,450 \mathrm{~kg} /$ ha (Huque et al.,2012) but productivity of India is very low and therefore high-yielding varieties need to be developed through utilization of valuable local and overseas germplasm collections. It is generally considered to be drought resistant compared to other leguminous crops (Belko et al. 2013; Fatokun et al. 2016). However, the ability to cope with low water potential vary significantly by the particular genotype (Watanabe et al. 1997 ; Muchero et al. 2008).

The seed coat acts as a barrier between the internal structures of the seed and the external environment and this further contributes to the protection of the embryo from mechanical injuries and attacks of pest 
diseases (Tiryaki et al. 2016; Weber et al. 1996). Additionally, seed coat colour due to pigmentation is an important quality trait, domestication trait and morphological marker, and is closely associated with water intake and drought (Ayeh et al. 2021). In addition, the seed coat ensures that seeds survival of seed in harsh environmental conditions (de Souza and Marcos-Filho, 2001). Research findings have proven that seed size and coat colour are important characteristics for distinguishing different varieties of Vicia sativa (Buyukkartal et al. 2013).

Pod yield of yardlong bean falls far below the potential of the crop due to many problems (Kongjaimun et al. 2010). High among production constraints of yardlong beans are insect pests attack, diseases infestation and weather failure (Dugje et al. 2009). Yellow Mosaic Disease (YMD) is the most important viral disease in yardlong bean reported from entire India. The key symptoms are bright yellow patches on the leaves interspersed with green areas, and slight puckering; seed production is affected (Naraini 1960).

Development of new varieties addressing the various problems can help reduce the yield deficit. However, breeding against constraints without consumer acceptability, considerations may result in the rejection of the improved varieties. Seed coat colour is an important criterion for acceptability of any improved varieties. Relationship between seed coat colour with yield traits and disease resistance is increased the acceptability of any varieties. This study was therefore, designed to evaluate the genotypes of different seed coat colour and their possible correlation with pod yield and disease resistance.

\section{Material And Methods}

\section{Plant material and seed multiplication}

In yardlong bean three seed coat colour is visible mostly visible in eastern India. Based on seed coat colour total nine genotypes, three genotypes of each seed coat was selected (Table 1). Genotype evaluation and seed multiplication was done at the experimental field of ICAR-Research Center for Eastern Region, Patna, Bihar, India. All genotype and their seeds were grown and purified more than two years before included in this study. Agronomical interventions like plot preparation, fertilizers, fungicides and insecticides application were conducted based on the recommended practices for the crop. Proper care was taken to segregate each other to assure individuality of genotype. Diversifying qualitative characters like flower color, pod color, seed color and some selected yield parameters like days of $50 \%$ flower, days of mature pods, average pod length, average pod width and pod yield per plant were measured as per minimum descriptors of NBPGR. 
Table 1

Source of genotypes used in this study

\begin{tabular}{|clllll|}
\hline S.N & Genotype & Source & $\begin{array}{l}\text { Seed coat } \\
\text { colour }\end{array}$ & $\begin{array}{l}\text { Plant growth } \\
\text { habit }\end{array}$ & $\begin{array}{l}\text { Pod pigmenta } \\
\text { tion }\end{array}$ \\
\hline 1 & YB-7 & Bangalore, India & Bicolour & Pole & Light green \\
\hline 2 & RCPY-2 & Patna, India & Bicolour & Pole & Light green \\
\hline 3 & RCPY-1 & Motihari, India & Bicolour & Pole & Dark green \\
\hline 4 & $\begin{array}{l}\text { IC- } \\
626154\end{array}$ & Kerala, India & Brown & Pole & Light green \\
\hline 5 & $\begin{array}{l}\text { IC- } \\
622602\end{array}$ & Kerala, India & Brown & Pole & Light green \\
\hline 6 & $\begin{array}{l}\text { IC- } \\
626152\end{array}$ & Kerala, India & Brown & Pole & Light green \\
\hline 7 & $\begin{array}{l}\text { IC- } \\
622601\end{array}$ & Kerala, India & Black & Pole & $\begin{array}{l}\text { Purple spot on whole pod } \\
\text { surface }\end{array}$ \\
\hline 8 & IC-626147 & Kerala, India & Black & Pole & $\begin{array}{l}\text { Light green pod with } \\
\text { purple tip }\end{array}$ \\
\hline 9 & IC-626153 & Kerala, India & Black & Pole & $\begin{array}{l}\text { Light green pod with } \\
\text { purple tip }\end{array}$ \\
\hline
\end{tabular}

\section{Seed quality and imbibition pattern}

To determine the rate of water absorption, the initial weight of dry seeds was recorded on a digital balance in gram, and the seeds were then placed in a $100 \mathrm{ml}$ beaker with $50 \mathrm{ml}$ of water, covered with an aluminium foil, and held at $25^{\circ} \mathrm{C}$. To determine water uptake in three different seed coat colours, the seeds of each genotype were weighed at one-hour interval for the first ten hours, then at 12-hour intervals until a plateau was reached.The surface of the seeds were dried using absorbent paper before and after each weighing, and the seeds were then placed back in the beaker. The percentage of water uptake (\%) was calculated as the increase in seed weight relative to the initial weight of the seeds.

Seven seeds of each genotype whose initial weights were measured were left to uptake water in moist paper in four replications at $25^{\circ} \mathrm{C}$. The seeds were weighed in $1 \mathrm{~h}$ intervals. The study was ended when germination started. Amounts (\%) of water uptake was calculated according to Demir et al. (2008) as follows:

$W_{2}=(100-A / 100-B) \times W_{1}$ 
Where: $W_{2}$ - indicates final seed weight; $W_{1}$ - indicates initial seed weight; $A$ - indicates initial seed moisture content; $B$ - indicates the final seed moisture content that seedlots reached

Standard germination test was conducted by keeping 10 seeds in germination paper $(200 \times 200 \mathrm{~mm})$ for 14 days at $25^{\circ} \mathrm{C}$. Seeds producing minimum $2 \mathrm{~mm}$ radical were counted as germinated seed.

\section{Mosaic severity recording}

Disease reaction was scored when $95 \%$ of the infector rows (PS 16) showed BCMV incidence under field conditions. The resistant plants did not show any mosaic symptoms on leaves or pods duringthe entire growth period, while the susceptible plants showed various grades of yellowing depending on the stages at which infection occurred. The disease rating was done using modified rating scale of Singh et al. 1988 (Table 2). Genotypes having different seed coat were classified into four reactions that is, susceptible (S), moderately susceptible (MS), moderately resistant (MR) and highly resistant (R) on the basis of disease scores and type of symptoms (Table 2).

Table 2

Reaction rating for Mung bean yellow mosaic India virus (MYMIV)

\section{Types of symptoms}

1 No visible symptoms or yellow specks on leaves or pods

2 Minute yellow specks on leaves without any symptoms on pods

3 No visible symptoms on leaves till flowering and showing yellowing and mottling of pods at maturity

4 Pronounced yellow mottling of foliage and discoloration of leaves and yellowing of pods and seeds

\section{Reaction}

R (Resistant)

MR (Moderately

Resistant)

MS (Moderately

Susceptible)

S ( Susceptible)

\section{Results And Discussion}

\section{Agro-morphological characterization}

The clear variation was observed, as the colour of pod varied from light green to dark green with and without purple tip. In spite of different seed coat colour all plants are pole type and need support to climb up (Table 1). Black seed coloured genotype (IC-630383, IC-626147) yielded green pod with purple tip (Fig. 1a) while patches of purple colour were observed in whole pod in the genotypes IC-622601 (Fig. 1b). Most of the economical important traits found in IC-622601 were similar to wild type Vigna sp. having an indeterminate growth habit, bearing small seeds, differs in the extent of hard seededness and pod dehiscence from the cultivated species as reported by several researcher (Hammer 1984; Andargie et al.,2014). These results indicated that, there is a strong relationship between black seed coat colour and evolution of yardlong bean. Additionally pigmentation in immature pod and can be considered as important morphological marker in breeding programs. Correlation between pod tip colours with black 
seed coat colour was also reported by Herniter et al., 2018. But different type of gene involved in seed coat colour, pod tip colour and pod pigmentation and their interaction is need to be studied.

Along with these qualitative traits some of selected seed parameters like seed length, seed width, seed thickness and yield related traits like days of $50 \%$ flower, days of mature pods, average pod length, average pod width and pod yield per plant were measured to study the relationship between seed coat colour, seed quality and yield related traits. The general statistical parameters for various characters are presented in Table 3.

Table 3

Estimates of variance for the traits studied in yardlong bean genotypes

\begin{tabular}{|lllllllll|}
\hline Parameters & $\begin{array}{l}\text { Seed } \\
\text { length } \\
\text { (cm) }\end{array}$ & $\begin{array}{l}\text { Seed } \\
\text { width } \\
\text { (cm) }\end{array}$ & $\begin{array}{l}\text { Seed } \\
\text { Thickness } \\
\text { (cm) }\end{array}$ & $\begin{array}{l}\text { Days } \\
\text { of 50\% } \\
\text { flower }\end{array}$ & $\begin{array}{l}\text { Days of } \\
\text { mature } \\
\text { pods }\end{array}$ & $\begin{array}{l}\text { Average } \\
\text { pod } \\
\text { length } \\
\text { (cm) }\end{array}$ & $\begin{array}{l}\text { Average } \\
\text { pod } \\
\text { width } \\
\text { (cm) }\end{array}$ & $\begin{array}{l}\text { Pod } \\
\text { yield } \\
\text { per } \\
\text { plant } \\
\text { (g) }\end{array}$ \\
\hline Mean & 1.1011 & 0.5078 & 0.4078 & 54.222 & 58.667 & 31.058 & 1.1500 & 878.22 \\
\hline SD & 0.2707 & 0.0756 & 0.0524 & 8.8003 & 11.192 & 10.810 & 0.6230 & 148.47 \\
\hline SE Mean & 0.0902 & 0.0252 & 0.0175 & 2.9334 & 3.7305 & 3.6033 & 0.2077 & 49.490 \\
\hline C.V. & 24.581 & 14.894 & 12.847 & 16.230 & 19.076 & 34.805 & 54.174 & 16.906 \\
\hline Minimum & 0.8000 & 0.4300 & 0.3300 & 43.000 & 41.000 & 17.600 & 0.6000 & 650.00 \\
\hline Maximum & 1.5300 & 0.6700 & 0.5000 & 70.000 & 77.000 & 44.250 & 2.6000 & 1170.0 \\
\hline
\end{tabular}

Correlation study (Table 4) among these quantitative traits indicated the significant positive correlation between seed length, seed width $(r=0.577)$ and seed thickness $(r=0.608)$. Days to $50 \%$ flowering trait was negatively significant with average pod length $(r=-0.7974)$ and pod yield per plant $(r=-0.4767)$. Days of $50 \%$ flower and days to mature pods showed significant positive $(r=0.7421)$ relationship with each other. Seed length $(r=0.6063)$ and average pod length $(r=0.6401)$ recorded highly significant positive correlation between pod yield per plant. However, days of $50 \%$ flower and days to mature pods showed significant negative correlation with pod yield per plant. Interestingly, days to $50 \%$ flowering indicated negative correlated with all three seed dimension parameters, seed length $(r=-0.3208)$, seed width $(r=-0.3485)$ and seed thickness $(r=-0.1452)$. Correlation study specified that there is a strong relationship between seed dimension and earliness of genotype as days to $50 \%$ flowering is indicator of earliness. Flowering time and seed size are the important traits for adaptation in Legumes. Early phenology (time of flowering, pod filling and maturity) enhance its adaptation to short season environments. Similar relationship was reported by Sundaram et al. (2019) found in kabuli chickpea. 
Table 4

Correlation analysis of morphological traits in yardlong bean

\begin{tabular}{|c|c|c|c|c|c|c|c|c|}
\hline Parameters & $\begin{array}{l}\text { Seed } \\
\text { length } \\
(\mathrm{cm})\end{array}$ & $\begin{array}{l}\text { Seed } \\
\text { width } \\
\text { (cm) }\end{array}$ & $\begin{array}{l}\text { Seed } \\
\text { Thickness } \\
\text { (cm) }\end{array}$ & $\begin{array}{l}\text { Days } \\
\text { of } 50 \% \\
\text { flower }\end{array}$ & $\begin{array}{l}\text { Days of } \\
\text { mature } \\
\text { pods }\end{array}$ & $\begin{array}{l}\begin{array}{l}\text { Average } \\
\text { pod } \\
\text { length }\end{array} \\
\text { (cm) }\end{array}$ & $\begin{array}{l}\text { Average } \\
\text { pod } \\
\text { width } \\
\text { (cm) }\end{array}$ & $\begin{array}{l}\text { Pod } \\
\text { yield } \\
\text { per } \\
\text { plant } \\
\text { (g) }\end{array}$ \\
\hline $\begin{array}{l}\text { Seed } \\
\text { length }(\mathrm{cm})\end{array}$ & 1 & & & & & & & \\
\hline $\begin{array}{l}\text { Seed width } \\
\text { (cm) }\end{array}$ & 0.5778 & 1 & & & & & & \\
\hline $\begin{array}{l}\text { Seed } \\
\text { Thickness } \\
\text { (cm) }\end{array}$ & 0.6085 & 0.8063 & 1 & & & & & \\
\hline $\begin{array}{l}\text { Days of } \\
50 \% \text { flower }\end{array}$ & -0.3208 & -0.3485 & -0.1452 & 1 & & & & \\
\hline $\begin{array}{l}\text { Days of } \\
\text { mature } \\
\text { pods }\end{array}$ & -0.0193 & 0.0448 & 0.0007 & 0.7421 & 1 & & & \\
\hline $\begin{array}{l}\text { Average } \\
\text { pod length }\end{array}$ & 0.5702 & 0.5296 & 0.3300 & -0.7974 & -0.5183 & 1 & & \\
\hline $\begin{array}{l}\text { Average } \\
\text { pod width }\end{array}$ & 0.5022 & 0.3383 & 0.6798 & 0.3842 & 0.4706 & -0.1308 & 1 & \\
\hline $\begin{array}{l}\text { Pod yield } \\
\text { per plant } \\
\text { (g) }\end{array}$ & 0.6063 & 0.0415 & 0.1945 & -0.4767 & -0.5326 & 0.6401 & -0.0623 & 1 \\
\hline
\end{tabular}

\section{Imbibition pattern}

Significant differences were observed between genotype of different seed coat with respect to increase in seed mass after $1 \mathrm{hrs}$ of soaking. The trend showed a general increase on average until after $24 \mathrm{hrs}$ (Fig. 2).All the genotypes selected for this study were of the same moisture content $\left({ }^{*} 10.3 \%\right)$. Imbibition curves indicated that water absorption and weight gain of seed were highest in bicolor seed coat coloured genotypes compared to brown and black seed coat coloured genotypes used in the study (Fig. 2).

Water uptake is reported to be highest in bicolor seed RCPY- 1 followed by RCPY-2 and germination of seed is also fastest in bicolor genotypes (YB-7, RCPY-2 and RCPY-1) as shown in Fig. 3 and 4. The highest water uptake during seed germination was observed in bicolor seed coat colour genotypes (RCPY$2>\mathrm{RCPY}-1>\mathrm{YB}-7)$. When the reading was taken on the 3rd day, it was observed that germination speed was also fastest in the bicolor genotypes compared to brown and black seed coat colour. The results showed that bicolour coloured seeds imbibed water more rapidly than black and brown coloured seeds. Fig. 4 (a, b) showes the speed of germination of different genotypes at 3rd day. These findings are similar 
to those by Chibarabada et al. (2014) who reported that dark coloured Bambara seeds absorbed water slowly than other coloured seeds. This delay in absorption may be caused by substances present on the seed coat or due to the internal part of the seeds, which can block the metabolism preparatory to germination or prevent the free access of oxygen to the embryo or the release of carbonic gas. Various kinds of germination inhibitors, such as tannins (responsible for dark coloured seed coat), phenolic acids, alkaloids and aldehydes are known (Marcos Filho 2005). It was interesting to notice that genotype IC630383 showed highest root elongation (Fig. 4a) among all genotype and moderate rate of water uptake. This genotype appears to be potential donor for abiotic stress-resilient breeding programs.

\section{Disease screening}

Yellow mosaic disease (YMD) is most devastating disease of cultivated legumes in South-East Asia. In Eastern India, YMD is caused by Mungbean yellow mosaic India virus (MYMIV) and belonging to the genus Begomovirus of the family Geminiviridae (Haq et al. 2010). MYMIV is widely distributed, causing 10-100\% yield losses once infected in standing crop of yardlong bean (Nene 1969, Nene et al. 1972, Chenulu et al. 1979, Marimuthu et al. 1981). In the fields, the leaves of symptomatic plants showed severe mosaic with bright yellow and vein-clearing symptoms and as the season advanced, the leaves showed bright yellow mosaic symptoms followed by necrosis and the death of infected plants.

The per cent disease intensity among the genotypes of different seed coat colour ranged from 6.25 to $78.25 \%$. All three bicolour seed coat colour genotypes (YB-7, RCPY-2 and RCPY-1) were resistant to MYMIV. However, brown seed coat coloured lines showed moderate resistance (IC-622602, IC-626152) to resistant (IC-626154) disease reaction (Table 5). Genotype IC-626154, showed minimum mosaic incidence (6.25\%). Black coloured seeds showed varied response to MYMIV. Among black coloured seeded genotype, IC-630383 was moderately resistant and IC-622601 was resistant. However, genotype IC-626147 was found to be moderately susceptible against MYMIV with highest mean mosaic incidence $78.25 \%$. Our findings concurred with previous findings by Islam et al. (2003) indicating the resistance of dark-coloured common bean cultivars involved in resistance to diseases and pests, and reducing tannin concentration may have a negative effect on plant resistance. 
Table 5

Reaction of yardlong bean genotypes against Yellow bean mosaic virus in field condition

\begin{tabular}{|c|c|c|c|}
\hline Genotypes & Seed colour & Mean $\left({ }^{x}\right)$ mosaic incidence $(\%)$ & Disease Reaction \\
\hline YB-7 & Bicolour & $12.00(20.24)^{b}$ & Resistant \\
\hline RCPY-2 & Bicolour & $8.00(16.39)^{\mathrm{a}}$ & Resistant \\
\hline RCPY-1 & Bicolour & $8.50(16.94)^{a}$ & Resistant \\
\hline IC-626154 & Brown & $6.25(14.47)^{a}$ & Resistant \\
\hline IC-622602 & Brown & $38.50(38.32)^{c}$ & Moderately Resistant \\
\hline IC-626152 & Brown & $35.75(36.70)^{c}$ & Moderately Resistant \\
\hline IC-630383 & Black & $34.35(35.88)^{c, d}$ & Moderately Resistant \\
\hline IC-626147 & Black & $78.25(62.21)^{\mathrm{e}}$ & Moderately Susceptible \\
\hline IC-622601 & Black & $15(22.71)^{b}$ & Resistant \\
\hline \multicolumn{4}{|c|}{ * Figures in parentheses are angular transformed values } \\
\hline \multicolumn{4}{|c|}{$\begin{array}{l}\text { ' } x \text { ' Means followed by the same letter in a column within each year are not significantly different } \\
\text { (P } P 0.05 \text { ) according to Fisher's protected least significant difference test using values after angular } \\
\text { transformation of the proportion of wilt. }\end{array}$} \\
\hline
\end{tabular}

\section{Conclusion}

This study reported relationship between seed coat colour and water uptake relation and yield related traits in yardlong bean genotypes. Bicolour genotype RCPY-2 was identified as high yielding and disease resistant genotype and advanced form of cultivated type while black seed coat were wild type. Seed coat may be used as an important parameter to prescreen high yield genotypes of yardlong bean. Additionally, the knowledge of seed coat colour and its linkage with identified potential germplasm appears to be possible donor for yellow mosaic disease resistant and water stress-resilient yardlong bean breeding programs.

\section{Declarations}

\section{Conflict of interest}

The authors declare that they have no conflict of interest on the manuscript's content and study undertaken.

\section{References}


1. Andargie M, Pasquet RS, Gowda BS, Muluvi GM, Timko MP (2014) Molecular mapping of QTLs for domestication-related traits in cowpea (V. unguiculata (L.) Walp.). Euphytica. Dec;200(3):401-12.

2. Ayeh, K, Peter, AK, Grace, AE, \& Enu-Kwesi, L (2021) Physiological, developmental and growth responses to desiccation induced stress in four seed coat colour varieties of Vigna unguiculata ( $L$. Walp). African Journal of Agricultural Research 17(4): 642-657

3. Belko N, Zaman AM, Diop NN, Cisse N, Zombre G, Ehlers JD, Vadez V (2013) Restriction of transpiration rate under high vapour pressure deficit and non-limiting water conditions is important forterminal drought tolerance in cowpea. Plant Biology15(2):304-316

4. Buyukkartal HN, Colgecen H, Pinar HN, Erdogan N (2013) Seed coat ultrastructure of hard-seeded and soft-seeded varieties of Vicia sativa. Turkish Journal of Botany 37(2):270-275

5. Chenulu V, Venkateshwarlu V V, Rangaraju R (1979) Studies on yellow mosaic disease of mungbean. Indian Phytopathology 32: 230-235

6. Chibarabada TP, Modi AT, Mabhaudhi T (2014) Seed quality characteristics of a bambara groundnut (Vigna subterranea L.) landrace differing in seed coat colour. South African Journal of Plant and Soil 31(4):219-226 Available at 10.1080/02571862.2014.966340

7. De Souza FHD, Marcos-Filho J (2001) The seed coat as a modulator of seed-environment relationships in Fabaceae. Brazilian Journal of Botany 24(4):365-375.

8. Dugje, IY, Omoigui, LO, Ekeleme, F , Kamara, AY, \& Ajeigbe, H (2009) Farmers' guide to cowpea production in West Africa. IITA, Ibadan, Nigeria 20: 12-14

9. Hall A (2012) Phenotyping cowpeas for adaptation to drought. Frontiers in Physiology 3:155

10. Hammer K (1984) Das domestikationssyndrom. Kulturpflanze 32:11-34

11. Haq QM, Arif A and Malathi VG (2010) Engineering Resistance against Mungbean Yellow Mosaic India Virus using Antisense RNA. Indian Journal of Virology 21(1): 82-85.

12. Haque MS, Azad A, Saha NR, Islam MM (2012) Genetic variability and correlation studies among yield and yield contributing characters of yardlong bean (Vigna unguiculata ssp. sesquipedalis $L$. Verdc.). Bangladesh Journal of Botany. 2021 Mar 27;50(1):93-101.

13. Herniter, IA, Muñoz-Amatriaín, M, Lo, S, Guo, YN, \& Close, TJ (2018) Identification of candidate genes controlling black seed coat and pod tip color in cowpea (Vigna unguiculata [L.] Walp) G3:Genes, Genomes, Genetics, 8(10):3347-3355

14. Islam, FMA, Rengifo, J Redden, RJ , Basford, KE, \& Beebe, SE (2003) Association between seed coat polyphenolics (tannins) and disease resistance in common bean. Plant Foods for Human Nutrition 58(4): 285-297

15. Kongjaimun, A, Somta, P, Tomooka, N, Kaga, A, Vaughan, DA , \& Srinives, P (2013) QTL mapping of pod tenderness and total soluble solid in yardlong bean [Vignaunguiculata (L.) Walp.subsp. unguiculata cv.-gr. sesquipedalis]. Euphytica 189(2): 217-223

16. Marcos Filho J (2005). Fisiologia de sementes de plantas cultivadas. Fealq. Piracicaba pp 495 
17. Marimuthu T, Subramanian CL and Mohan R (1981) Assessment of yield losses due to yellow mosaic infection in mungbean. Pulse Crop News Letter 1:104

18. Muchero W, Ehlers D, and Roberts, PA (2008) Seedling stage drought-induced phenotypes and drought-responsive genes in diverse cowpea genotypes. Crop Sci 48:541-552. doi: 10.2135/cropsci2007.07.0397

19. Naraini TK (1960) Yellow mosaic of mung (Phaseolus aureus L.) Indian Phytopathology 13: 24-29

20. Nene YL, Srivastava SK, Naresh JS (1972) Evaluation of urdbean (Phaseolus mungo L.) and mungbean (Phaseolus aureus L.) germplasm and cultivars against yellow mosaic virus. Indian Journal of Agriculture Science 42: 251-254

21. Nene YL (1969) A survey of viral diseases of pulse crops in Uttar Pradesh. Second Annual Report from Uttar Pradesh Agric. University pp 25

22. Pasquet R (2001) Vigna Savi. In: Mackinder B, Pasquet R, Polhill R,Verdcourt B (Eds.), Flora Zambesiaca, 3 part Phaseoleae. Royal Botanic Gardens, Kew pp. 121-156

23. Singh G, Kapoor S, Singh K (1988) Multiple disease resistance in mungbean with special emphasis on mungbean yellow mosaic virus. Mungbean: Proceedings of Second International Symposium on Mungbean, Shanhua, Asian Vegetable Research and Development Centre, Tainan, Taiwan, pp 290296

24. Sundaram P, Samineni S, Sajja S B Roy, C Singh, S P Joshi, P \& Gaur P M. (2019) Inheritance and relationships of flowering time and seed size in kabuli chickpea. Euphytica, 215(9): 1-14.

25. Timko MP, Singh BB (2008) Cowpea a multifunctional legume. Genomics of Tropical Crop Plants.New York: Springer pp. 227-258

26. Tiryaki GY, Cil A, Iskender TI (2016) Revealing seed coat colour variation and their possible association with seed yield parameters in common vetch (Vicia sativa L.) International Journal of Agronomy. Available at http://dx.doi.org/10.1155/2016/1804108

27. Verdcourt, B (1970) Studies in the leguminosae-Papilionoideae for the flora of tropical East Africa: IV , Kew Bulletin, 24( 3): 507-569, www.jstor.org/stable/4102859.

28. Watanabe, S, Hakoyama, S, Terao, T, and Singh, B B (1997) Evaluation methods for drought tolerance of cowpea, in Advances in Cowpea Research, eds B B Singh, D R Mohan Raj, K E Dashiell, and L E N Jackai Ibadan IIT pp 87-97

29. Weber H, Borisjuk L, Wobus U (1996) Controlling seed development and seed size in Vicia faba. A role for seed coat-associated invertases and carbohydrtae state. Plant Journal 10 (5):823-834

\section{Figures}



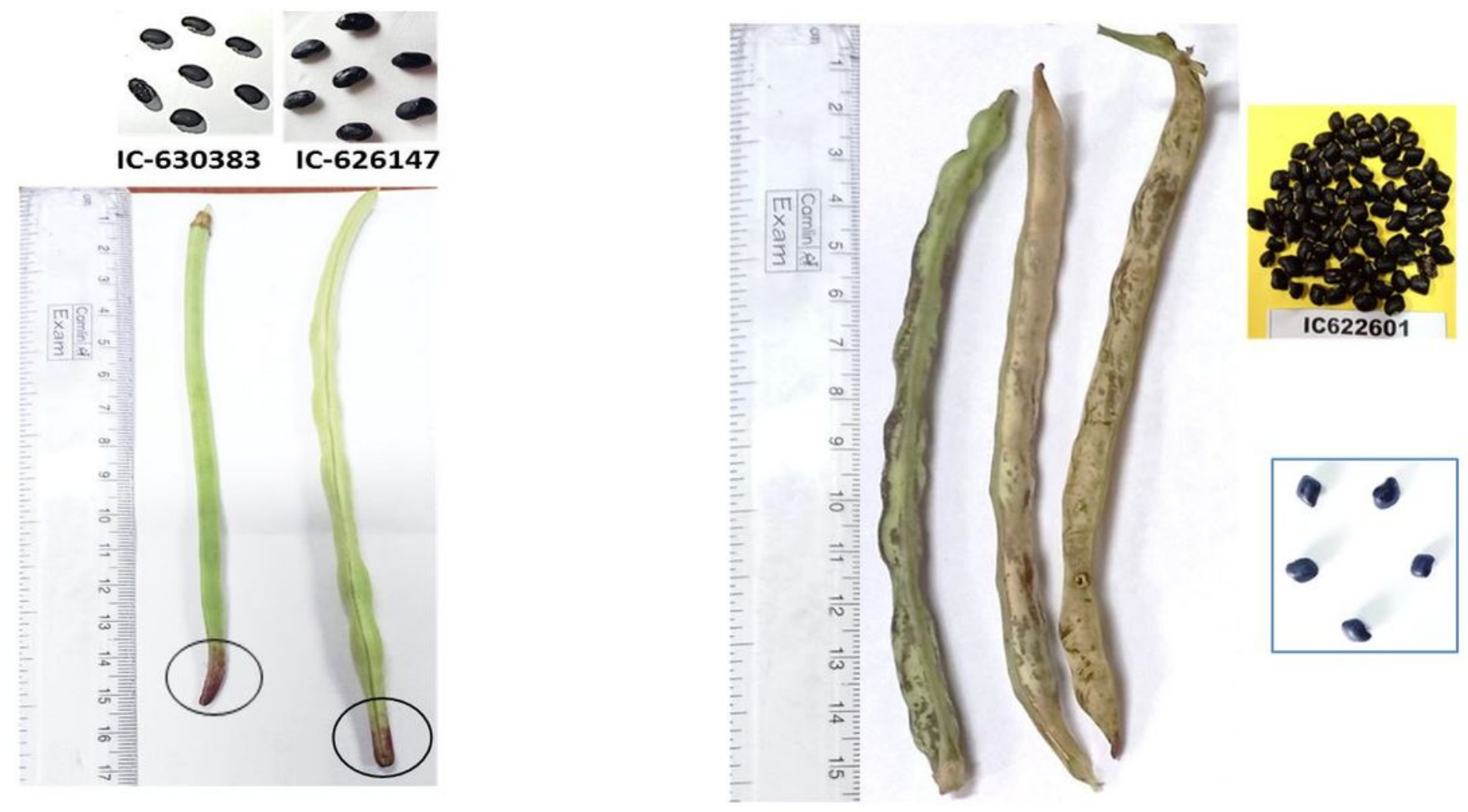

\section{Figure 1}

1a. Black seed coat coloured genotype (IC-630383, IC-626147) yielded green pod with purple tip; 1b. Black seed coat coloured genotype patches of purple colour were observed in whole pod in the genotypes IC622601

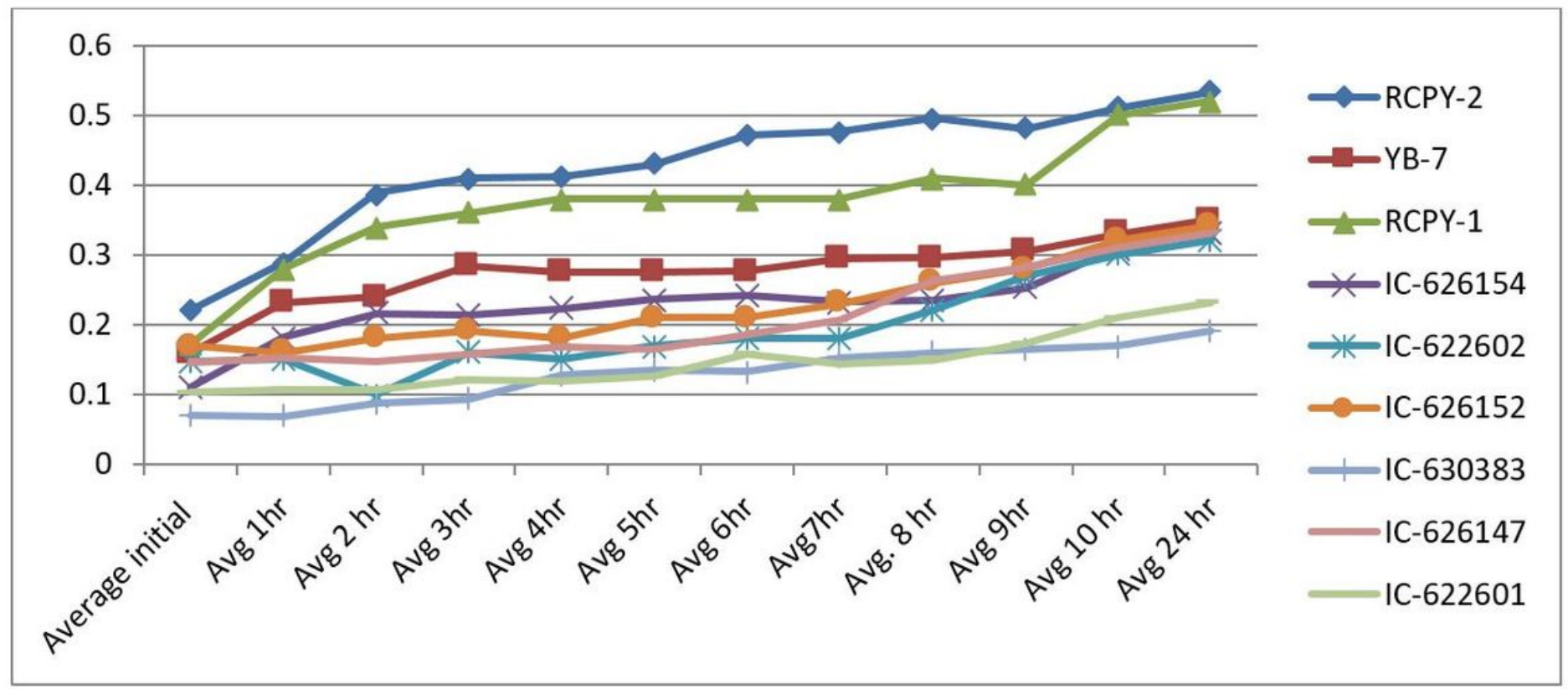


Figure 2

Imbibition curves of yardlong bean genotypes of different seed coat colour

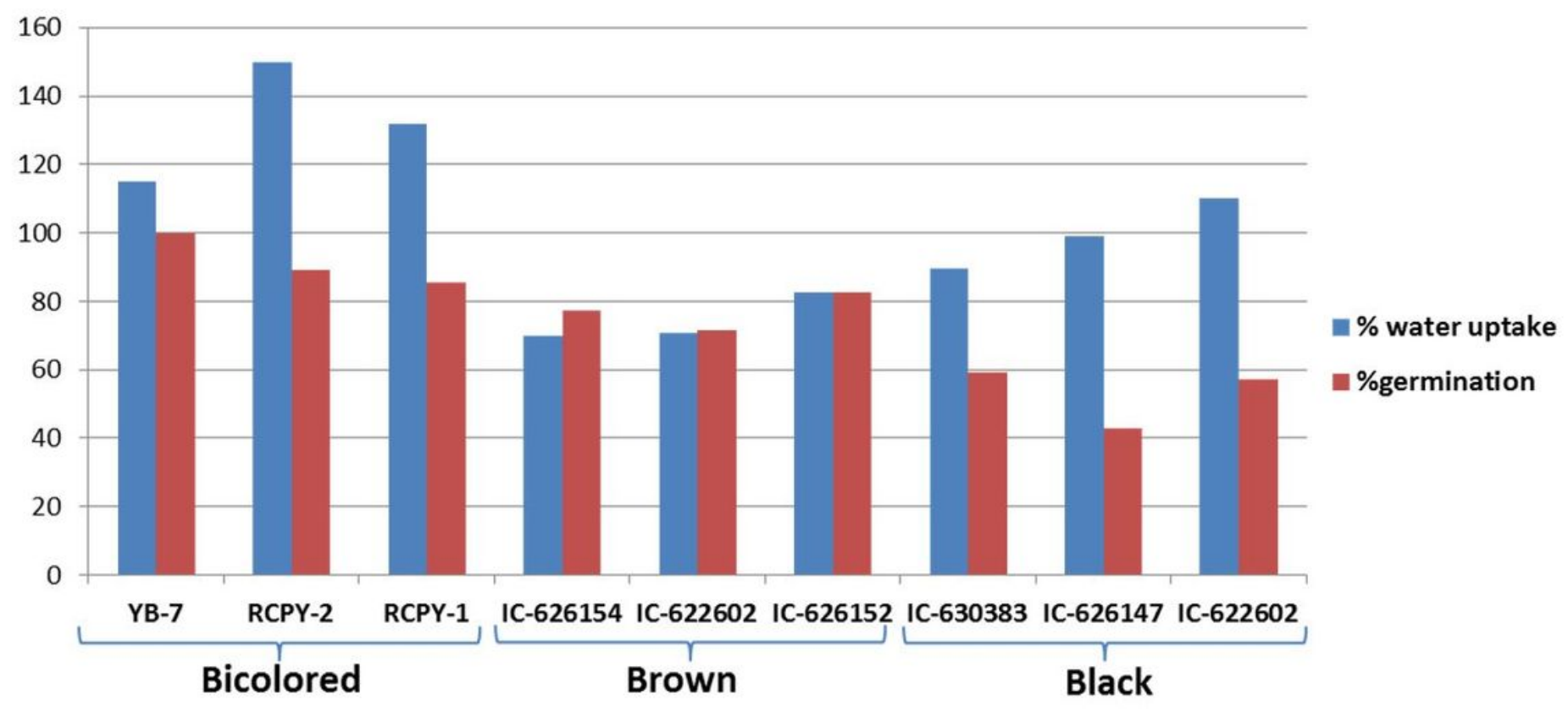

Figure 3

Water uptake and germination percentage of yardlong bean genotypes of different seed coat colour (bicolored, brown, black) 


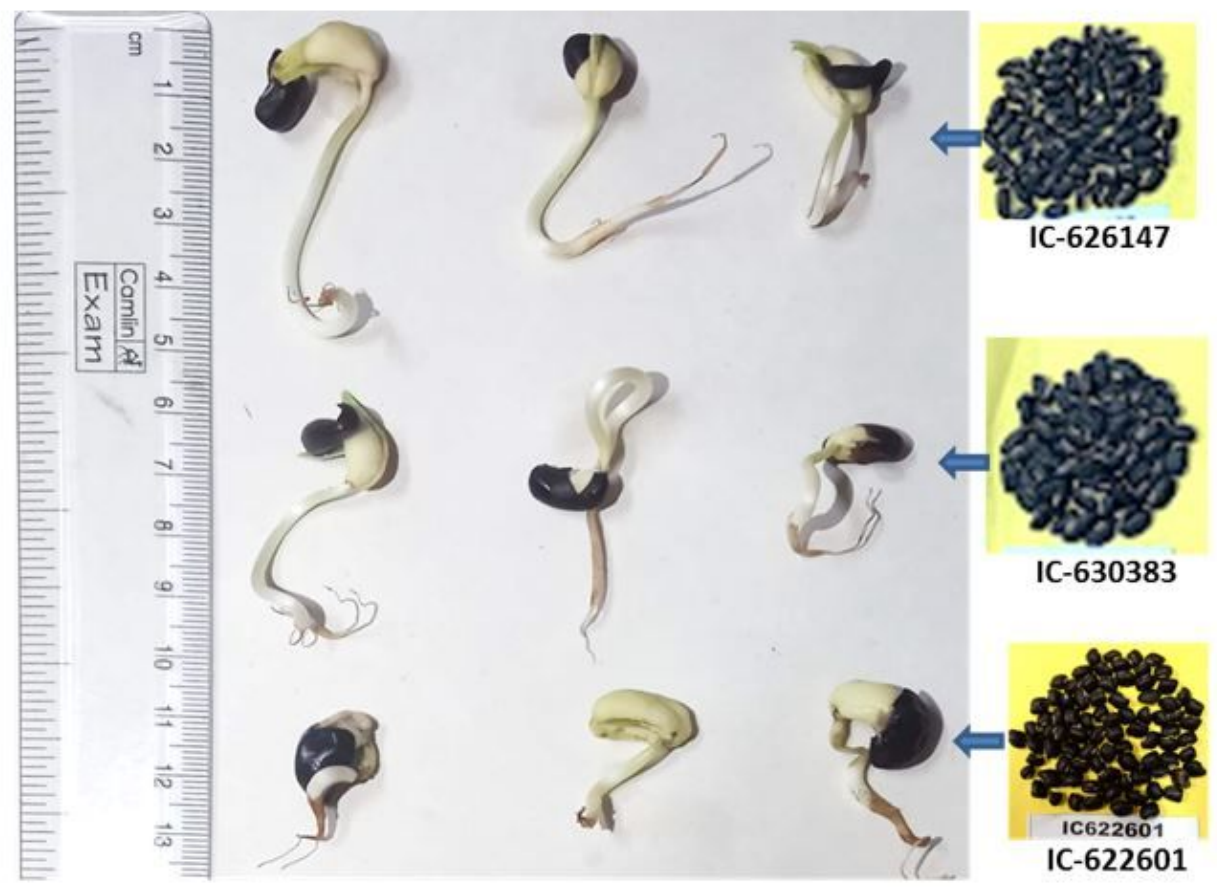

Figure 4 (a)

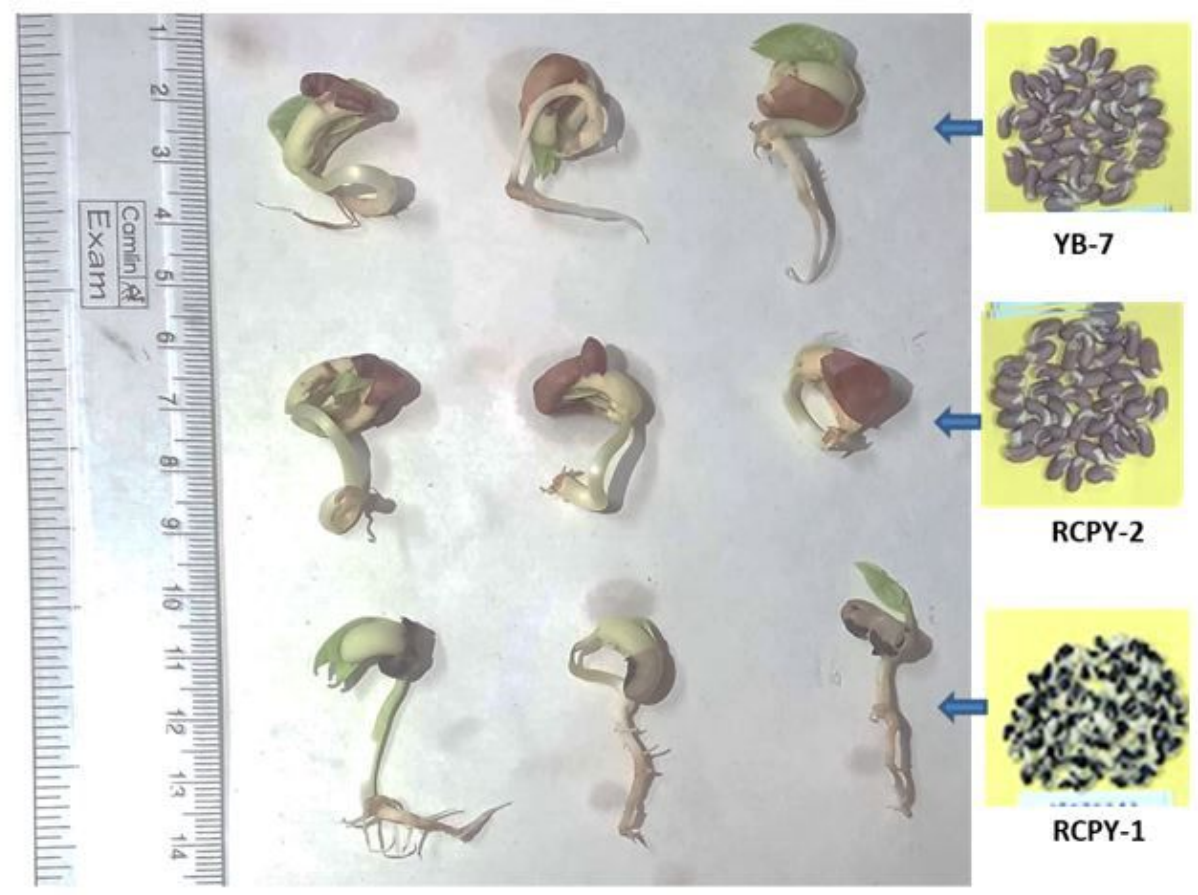

Figure 4 (b)

Figure 4

(a) showed the speed of germination of black seed coat yardlong bean genotype

(b) showed the speed of germination of bicolored seed coat yardlong bean genotype 